\title{
Pharmacologic and toxicologic properties of lyophilic extract Achillea setacea Waldst. et Kit.
}

\author{
G. P. Smoylovska, O. V. Mazulin, A. V. Abramov, N. V. Bukhtiyarova \\ Zaporizhzhia State Medical University, Ukraine
}

Infusions based on Achillea setacea Waldst. et Kit. are traditionally used as antiinflammatory, hepatic, appetizing, spasmolytic agents, they are used as well in hemorrhages of different etiology, thrombophlebitis and varicose ulcers. Diverse pharmacologic properties are due to the presence of essential oils, proazulene, sesquiterpenic lactones, hydroxycinnamomic acids, flavonoids, vitamin $\mathrm{K}_{1}$ in medicinal raw materials.

In using infusion phylloquinone, ascorbinic acid, flavonoids, hydroxycinnamomic acids, Calcium salts, tannins, achileine contribute to regulation of blood coagulation. It is very timely to assess hemostatic activity for lyophilic plant extracts which are perfectly soluble in water and have high biologic availability.

The aim of research is to assess the degree of acute toxicity and hemostatic activity for lyophilic extract of herb Achillea setacea Waldst. et Kit.

Materials and methods. Lyophilic extracts based on infusion of herb Achillea setacea Waldst. et Kit. obtained by dry sublimation have been used for the research. Lyophilic extracts obtained have been standardized for available vitamin $\mathrm{K}_{1}$ and have been studied for acute toxicity and hemostatic activity. Studying blood coagulation system has been carried out in animals with experimental toxic hepatitis for the following indices: blood coagulation time, prothrombin time, fibrin concentration in the blood.

Key words: Achillea, hemostatic activity, phyllochinone.

Zaporozhye medical journal 2017; 19 (6), 823-826 DOI: 10.14739/2310-1210. 2017.6.115308

E-mail: smoilovskaj@ukr.net

Results. Lyophilic extract based on Achillea setacea Waldst. et Kit. is friable amorphous light yellow mass with bitter taste, containing phylloquinone in concentration $5.79 \pm 0.05 \%$. When studying acute toxicity median lethal dose for lyophilic extracts of Achillea setacea Waldst. et Kit. was above $2000 \mathrm{mg} / \mathrm{ml}$ (practically nontoxic ones). Course therapy of extract Achillea setacea Waldst. et Kit. and solution of "Vikasol" for animals with toxic hepatitis led to decreasing hypocoagulation: decreasing prothrombin time and clotting time, increasing fibrin concentration in the blood up to $14.2 \pm 1.2 \mathrm{mg} / \mathrm{ml}$.

Conclusions. Studying lyophilic extracts of Achillea setacea Waldst. et Kit. standardized on vitamin $\mathrm{K}_{1}$ for acute toxicity allows to attribute them to VI class of toxicity. Administration of lyophilic extract Achillea setacea Waldst. et Kit. in dose $100 \mathrm{mg} / \mathrm{ml}$ resulted in decreasing hypocoagulation displaying in decreasing clotting time, in decreasing prothrombin time and increasing available fibrin in the blood. These indices exceeded by its activity reference medicine "Vikasol" $(6 \mathrm{mg} / \mathrm{kg})$.

\section{Фармако-токсикологічні властивості ліофільного екстракту Achillea setacea Waldst. et Kit.}

\section{Г. П. Смойловська, О. В. Мазулін, А. В. Абрамов, Н. В. Бухтіярова}

Настій із трави Achillea setacea Waldst. et Kit. традиційно використовують як протизапальний, апетитний, гепатопротекторний, спазмолітичний засіб, застосовують для зупинки кровотеч різної етіології, при тромбофлебітах і варикозних виразках. Багатогранні фрармакологічні властивості зумовлені наявністю в лікарській сировині ефірних олій, проазулену, сесквітерпенових лактонів, гідроксикоричних кислот, фрлавоноїдів, вітаміну $\mathrm{K}_{1}$.

У процесі регуляції згортання крові під час використання настою беруть участь філохінон, аскорбінова кислота, флавоноїди, гідроксикоричні кислоти, солі кальцію, дубильні речовини, ахілеїн. Актуальним є визначення гемостатичної активності ліофільних екстрактів рослини, що добре розчинні у воді та мають високу біологічну доступність.

Мета роботи - визначення гострої токсичності та гемостатичної активності ліофільного екстракту трави деревію щетинистого.

Матеріали та методи. Для дослідження використовували ліофільні екстракти, що отримали з настою трави деревію щетинистого методом сублімаційного сушіння. Отримані ліофільні екстракти стандартизували за вмістом вітаміну $\mathrm{K}_{1} \mathrm{i}$ досліджували на гостру токсичність і гемостатичну активність. Дослідження системи згортання крові проводили у тварин з експериментальним токсичним гепатитом за такими показниками, як-от: час згортання крові, протромбіновий час і концентрація фібрину у крові.

Результати. Ліофільний екстракт деревію щетинистого, котрий одержали, являє собою пухку аморфну масу світло-жовтого кольору з гірким смаком, що містить філохінон у концентрації 5,79 $\pm 0,05 \%$. При дослідженні гострої токсичності середня смертельна доза для досліджуваних ліофільних екстрактів деревію щетинистого становила понад 2000 мг/кг (практично не токсичні). Курсове призначення тваринам із токсичним гепатитом екстракту деревію та розчину вікасолу призводило до зменшення проявів гіпокоагуляції: зменшення протромбінового часу та часу згортання крові, підвищення концентрації фібрину у крові до $14,2 \pm 1,2$ мг/мл.

Висновки. Дослідження на гостру токсичність стандартизованих по вітаміну К ліофільних екстрактів деревію щетинистого дало можливість віднести їх до VI класу токсичності. Призначення тваринам із токсичним гепатитом ліофільного екстракту деревію щетинистого в дозі 100 мг/кг призводило до зменшення проявів гіпокоагуляції, яке виявлялось у зменшенні часу згортання крові, протромбінового часу, а також збільшення вмісту фібрину у крові в значеннях, що перевищують за своєю активністю рефреренс-препарат вікасол (6 мг/кг). 
Кмючевые слова: тысячелистник щетинистый, гемостатическая активность, фиммохинон.

Запорожский медицинский журнал. - 2017. T. 19, № 6(105). C. 823-826

\title{
Фармако-токсикологические свойства миофильного экстракта Achillea setacea Waldst. et Kit.
}

\author{
Г. П. Смойловская, А. В. Мазулин, А. В. Абрамов, Н. В. Бухтиярова
}

Настой из травы Achillea setacea Waldst. et Kit. традиционно используют как противовоспалительное, аппетитное, гепатопротекторное, спазмолитическое средство, применяют для остановки кровотечений различной этиологии, тромбофлебитах и варикозных язвах. Многогранные фармакологические свойства обусловлены наличием в лекарственном сырье эфирных масел, проазулена, сесквитерпеновых лактонов, гидроксикоричных кислот, фрлавоноидов, витамина К. В процессе регуляции свертывания крови при использовании настоя принимают участие филлохинон, аскорбиновая кислота, флавоноиды, гидроксикоричные кислоты, соли кальция, дубильные вещества, ахилеин. Актуальным является определение гемостатической активности лиофильных экстрактов растения, которые хорошо растворимы в воде и имеют высокую биологическую доступность.

Цель работы - определение острой токсичности и гемостатической активности лиофильного экстракта травы тысячелистника щетинистого.

Материалы и методы. Для проведения исследования использовали лиофильные экстракты, полученные из настоя травы тысячелистника щетинистого методом сублимационной сушки. Полученные лиофильные экстракты стандартизировали по содержанию витамина К и исследовали на острую токсичность и гемостатическую активность. Исследование свертывающей системы крови проводили у животных с экспериментальным токсическим гепатитом по таким показателям, как время свертывания крови, протромбиновое время и концентрация фибрина в крови.

Результаты. Полученный лиофильный экстракт тысячелистника щетинистого представляет собой рыхлую аморфную массу светло-желтого цвета с горьким вкусом, содержащий филлохинон в концентрации 5,79 0,05 \%. При исследовании острой токсичности средняя смертельная доза для исследуемых лиофильных экстрактов тысячелистника щетинистого составляла свыше 2000 мг/кг (практически не токсичные). Курсовое назначение животным с токсическим гепатитом экстракта тысячелистника и раствора викасола приводило к уменьшению проявлений гипокоагуляции: уменьшению протромбинового времени и времени свертывания крови, повышению концентрации фибрина в крови до 14,2 $\pm 1,2$ мг/мл.

Выводы. Исследование стандартизированных по витамину К лиофильных экстрактов тысячелистника щетинистого на острую токсичность позволило отнести их к VI классу токсичности. Назначение животным с токсическим гепатитом лиосильного экстракта тысячелистника щетинистого в дозе 100 мг/кг приводило к уменьшению проявлений гипокоагуляции, которое проявлялось в уменьшении времени свертывания крови, протромбинового времени, а также увеличении содержания фибрина в крови в значениях, превышающих по своей активности референс-препарат викасол (6 мг/кг).

Genus Achillea L. is known by diversity of species and contains more than 200 species of 13 groups, 4 groups are in flora of Ukraine. Group Millefolium (Mill) Koch is distinguished by its vast variety and is the most numerous one. Achillea millefolium L., Achillea submillefolium L., Achillea collina Heimerl, Achillea pannonica L., Achillea setacea Waldst. et Kit., et cetera are the most interesting among them [1].

Achillea setacea Waldst. et Kit. is widely distributed from Atlantic littoral in Europe up to Central Asia. The infusion based on the herb is traditionally used as anti-inflammatory, appetizing, hepatic, spasmolytic agents and it is used as hemostatic for hemorrhages of different etiology (uterine, hemorrhoid, gastric, pulmonary, nasal), in thrombophlebitis and varicose ulcers. It is often used in stomatology for bleeding gums, parodontosis, stomatitis, gingivitis [2-5].

Various pharmacologic properties are due to the availability in medicinal raw material essential oils (antibacterial effect), proazulene and sesquiterpene lactones (anti-inflammatory effect), hydroxycinnamomic acids (choleretic), flavonoids (spasmolytic), vitamin $\mathrm{K}_{1}$ (hemostatic) [2-6].

Phylloquinone exerts complex influence on human body: it stimulates blood clotting system, taking part in biosynthesis of prothrombin complex, furthers normalizing blood coagulation, it influences on cholesterol concentration in plasma. General hemostatic effect becomes evident both in direct contact with the wound and in internal administration.

Besides phylloquinone, ascorbic acid, flavonoids, hydrocinnamomic acids, Calcium salts, tannins, achilleine take part in regulating blood coagulation [6]. It has been experimentally determined that mechanism of hemostatic effect in drugs of Achillea setacea Waldst. et Kit. is based on increasing thrombocytes number and decreasing hemorrhage time. However, the mechanism of this effect is not elucidated yet, but the administration of drugs based on it never leads to thrombosis.

Taking in composition of biologic substances in the herb Achillea setacea it would be advisable for assessing hemostatic activity to use lyophilic extracts easily soluble in water, which are easily dosed out and possess high biologic availability.

\section{Aim of research}

Assessment of acute toxicity and hemostatic activity for lyophilic extract based on herb Achillea setacea Waldst. et Kit. in Ukraine flora.

\section{Materials and methods}

As object for research used air-dry over-ground part of Achillea setacea, stored up within the period of plant flowering (June - July) in Zaporizhzhia region, was used.

Lyophilic extract was obtained in aseptic conditions out of aqueous herb infusion (1:10) with using apparatus for sublimate drying KC-30. For this purpose aqueous infusion was bottled in $500 \mathrm{ml}$ vessels, it was placed into spirituous bath at temperature $-40{ }^{\circ} \mathrm{C}$ for 60 minutes for freezing by regular layer on internal surface of bottles. After freezing the bottles were placed for tempering to refrigerator at temperature $-30^{\circ} \mathrm{C}$ for 12 hours. Sublimator was cooled to temperature $-30^{\circ} \mathrm{C}$, then the bottles prepared were placed in apparatus and vacuum pump was engaged. 10-16 hours 
after the drying started, the temperature was increased slowly for heating cassette till $+40^{\circ} \mathrm{C}$. In unloading the bottles were closed with rubber corks and were corked with caps.

Lyophilic extracts were standardized for available vitamin $\mathrm{K}_{1}$. For this purpose accurate quantity of lyophilic extract (about $0.05 \mathrm{gr}$ ) was soluble in $50 \mathrm{ml}$ ethanol $70 \%$, filtrated through paper filter and washed with the same solvent, then the volume was added up to $100 \mathrm{ml}$. Optic density of solution was measured on spectrophotometer with the layer $10 \mathrm{~mm}$ at the wave $265 \mathrm{~nm}$. Ethanol $70 \%$ was used as the solution for comparison. Simultaneously optic density was measured for WSS "Vikasol".

Standardized lyophilic extracts have been studied for acute toxicity and hemostatic activity in Research Laboratory at Zaporizhzhia State Medical University.

Studying acute toxicity for lyophilic extract Achillea setacea Waldst. et Kit. has been performed according to the requirements of Ministry of Health of Ukraine [7]. Researches has been carried out on non-linear white rats with weight 180-200 gr delivered from Institute of Pharmacology and Toxicology Academy of Medical Sciences of Ukraine.

Dichlorethane was used for simulating toxic hepatitis; $500 \mathrm{mg} / \mathrm{kg}$ were introduced once within four days to the rats intragastric with metal atraumatic probe as $50 \%$ solution in sunflower seed oil purified. Introducing toxic agent was stopped on the fifth day, but all animals in investigated groups were given intragastric once a day $100 \mathrm{mg} / \mathrm{kg}$ lyophilic extract Achillea setacea Waldst. et Kit. with metal probe intragastric once a day within ten days. All animals were weighed and examined every day within 15 days. Examination included assessment of general state and behavior. Laboratory and biochemical investigations have been done on the 16-th day of research.

Studying blood coagulation system was done on animals with experimental toxic hepatitis for the following indices: clotting time, prothrombin time and fibrin concentration in the blood [8]. Solution of "Vikasol" was used for comparison; it was administered in analogic scheme as lyophilic extract Achillea setacea Waldst. et Kit. in dose 6 mg/kg, corresponding to phylloquinone amount in lyophilic extract. Every group was composed of ten animals.

Statistic reading the data after research was carried out by methods of mathematics statistic with using sets of applied programs Statistica for Windows 6.0, (StatSoft Inc. № AXXR712D833214FAN5) and Microsoft Office Excel 10. Reliability of data obtained was assessed by t-criterion Student. Reliable distinctions were those with meanings more than $95 \%(p<0.05)$.

\section{Results and discussion}

Lyophilic extract based on Achillea setacea Waldst. et Kit. is a friable amorphous light yellow mass odor free with bitter taste. The researches performed have shown that the yield of lyophilic extract of Achillea setacea Waldst. et Kit. was $29.15 \pm 2.33 \%$. Standardization of lyophilic extract has been carried out by spectrophotometry for available vitamin $\mathrm{K}_{1}$. Metrologic characteristics of assessment are presented in Table 1.

The data obtained display transition of great amount of phylloquinone to lyophilic extract (up to $5.79 \pm 0.05 \%$ ) with the error for single measuring is $0.8 \%$.
Table 1. Metrologic characteristics for results of studying available vitamin $\mathrm{K}_{1}(\%)$ in lyophilic extract based on herb Achillea setacea Waldst. et Kit. $(n=6)$

\begin{tabular}{|c|c|c|c|c|c|c|c|c|}
\hline \multirow[t]{2}{*}{ Plant } & \multicolumn{8}{|c|}{ Metrologic characteristics } \\
\hline & $\overline{\bar{x}}$ & $\mathrm{~S}$ & $\mathrm{~S}_{\overline{\mathrm{x}}}$ & $p$ & $t(p, v)$ & $\Delta \mathbf{x}$ & $\overline{\mathrm{x}} \pm \Delta \overline{\mathrm{x}}$ & $\bar{\varepsilon}$ \\
\hline A. setacea Waldst. et Kit. & 5.79 & 0.04 & 0.02 & 0.95 & 2.571 & 0.11 & $5.79 \pm 0.05$ & 0.8 \\
\hline
\end{tabular}

Table 2. Influence of using lyophilic extract Achillea setacea Waldst. et Kit. on indices of blood clotting system for experimental toxic hepatitis $(n=10)$

\begin{tabular}{lllc}
\hline Drug; group & $\begin{array}{l}\text { Prothrombin } \\
\text { time, second }\end{array}$ & $\begin{array}{l}\text { Clotting time, } \\
\text { second }\end{array}$ & $\begin{array}{l}\text { Fibrin } \\
\text { concentration } \\
\text { in blood, } \mathrm{mg} / \mathrm{ml}\end{array}$ \\
\hline Intact group & $16.2 \pm 1.4$ & $146 \pm 29$ & $15.3 \pm 1.3$ \\
$\begin{array}{l}\text { Group with toxic non-treated hepatitis } \\
\text { Group suffering from toxic hepatitis, } \\
\text { taking lyophilic extract Achillea setacea }\end{array}$ & $17.0 \pm 2.7^{*}$ & $178 \pm 13^{*}$ & $10.0 \pm 1.7$ \\
$\begin{array}{l}\text { Waldst. et Kit. (100 mg/kg) } \\
\begin{array}{l}\text { Group with toxic hepatitis, taking Vikasol } \\
(6 \mathrm{mg} / \mathrm{kg})\end{array}\end{array}$ & $18.0 \pm 2.6^{*}$ & $185 \pm 17^{*}$ & $13.0 \pm 1.2^{*}$ \\
\hline
\end{tabular}

*: $P<0.05$

While studying acute toxicity it has been revealed that the lethal dose for lyophilic extracts of Achillea setacea Waldst. et Kit. was above $2000 \mathrm{mg} / \mathrm{kg}$ in intragastric introduction. Thus, the samples mentioned are referred to $\mathrm{VI}$ class (practically non-toxic).

Results of studying blood clotting system in animals with toxic hepatitis are presented in Table 2.

After introducing dichlorethane to the rats, clotting disorder occurred and it was demonstrated by increasing the time of blood coagulation and prothrombin time, as well as decreasing amount of fibrin in blood in comparison with intact group.

Systemic administration of extract Achillea setacea (100 mg/kg) and Vikasol solution $(6 \mathrm{mg} / \mathrm{kg}$ ) to the animals suffering from toxic hepatitis led to decreasing symptoms of hypocoagulation. Indices of prothrombin time for the animals in control group were $28.3 \pm 2.0 \mathrm{~s}$., for the animals taking extract of Achillea setacea it was $17.0 \pm 2.7 \mathrm{~s}$. and for the animals taking Vikasol prothrombin time was $18.0 \pm 2.6 \mathrm{~s}$. Time for blood clotting in animals of control group was $274 \pm 25$ s., in animals taking lyophilic extract of Achillea setacea and Vikasol it was $178 \pm 13 \mathrm{~s}$. and $185 \pm 17 \mathrm{~s}$. relatively. Concentration of fibrin in the blood of animals with toxic hepatitis in control group was decreased to $10.0 \pm 1.7 \mathrm{mg} / \mathrm{ml}$. Therapy with lyophilic extract Achillea setacea Waldst. et Kit. promoted increasing fibrin amount to $14.2 \pm 1.2 \mathrm{mg} / \mathrm{ml}$.

\section{Conclusions}

1. Lyophilic extracts based on Achillea setacea Waldst. et Kit. have been standardized for amount of vitamin $\mathrm{K}_{1}$ (phylloquinone).

2. Studying acute toxicity of lyophilic extracts Achillea setacea Waldst. et Kit. in intragastric introdution was allows to attribute them to $\mathrm{VI}$ class of toxicity.

3. Course prescription of lyophilic extract Achillea setacea Waldst. et Kit. dosed $100 \mathrm{mg} / \mathrm{kg}$ (available phylloquinone $5.79 \pm 0.05 \%$ ) to the animals with toxic hepatitis led to decreasing signs of hypocoagulation, that was evident in decreasing clotting time and prothrombin time and increasing fibrin amount in the blood in the meanings exceeded reference-drug "Vikasol" in their activity $(6 \mathrm{mg} / \mathrm{kg})$. 
4. The results obtained are an experimental ground for making complex hemostatic drugs based on lyophilic extracts Achillea setacea Waldst. et Kit. revealing hemostatic activity.

\section{References}

[1] Benedek, B., Gjoncaj, N., Saukel, J., \& Kopp, B. (2007). Distribution of phenolic compounds in Middleeuropean taxa of the Achillea millefolium L. aggregate. Chem. Boidivers, 4(5), 849-857. doi: 10.1002/ cbdv.200790072.

[2] Taşkın, D., \& Dölen, E. (2016). Antioxidant Capacity, Total Phenolic and Flavonoid Contents in flowers of Achillea setacea. International Journal of Pharmaceutical Science and Health Care, 6(3), 32-38.

[3] Canan Karaalp, Ayse Nur Yurtman, N. Ulku Karabay Yavasoglu (2008). Evaluation of antimicrobial properties of Achillea L. flower head extracts. Pharmaceutical Biology, 47(1), 86-91. doi: 10.1080/13880200802448682

[4] Kyslychenko, O. A. (2014). Flavonoids determination in the aboveground part of Achillea millefolium. Ukrainskyi medychnyi almanakh, 17(3), 46-48.

[5] Smoilovskaya, L. G. P., Mazulin, A. V., \& Svetashov, O. M. (2014). Bakteriostatychna aktyvnist efirnykh olii deiakykh predstavnykiv sektsii Millefolium Koch. rodu Achillea [The bacteriostatic activity of essentia oils for some specimen Millefolium Koch. genus Achillea]. Curren issues in pharmacy and medicine: science and practice, 3(16), 40-45. [in Ukrainian]. doi: http://dx.doi.org/10.14739/2409-2932.2014.3.32852.

[6] Smoylovska, H. P., \& Mazulin, O. V. (2007). Spektrofotometrychne vyznachennia vitaminu $\mathrm{K} u$ travi vydiv rodu Achillea L. [Spectrophotometric determination of vitamin $\mathrm{K}$ in the herb of Achillea $\mathrm{L}$. species]. Farmatsevtychnyi chasopys, 1(1), 101-103. [in Ukrainian]. doi: http:// dx.doi.org/10.11603/2312-0967.2007.1.3127.

[7] Stefanov, A. V. (2002). Doklinicheskie issledovaniya lekarstvennykh sredstv [Preclinical studies of medicinal products]. Kyiv: Avicenna [in Russian]

[8] Kozlov, A. A., Natrus, L. V., Chernovol, P. A., Melkumian, A. L., Konoplianko, V. A., Snehir, M. A. \& Prostakova, T. M. (2011). Laboratornaya diagnostika sistemy gomeostaza [Laboratory diagnostics of homeostasis]. Moscow: Littera [in Russian].

\section{Information about authors:}

Smoylovska G. P., Ph.D., docent of the Department

of Pharmacognosy, Pharmaceutical Chemistry and Medicina

Preparations Technology, Zaporizhzhia State Medical University,

Ukraine.

Mazulin 0. V., Dr.hab., professor, head of the Department

of Pharmacognosy, Pharmaceutical Chemistry and Medicinal

Preparations Technology, Zaporizhzhia State Medical University,

Ukraine.

Abramov A. V., MD, PhD, Professor of the Department of Pathologic

Physiology, Zaporizhzhia State Medical University, Ukraine.

Bukhtiyarova N. V., MD, PhD, docent of the Department

of Pharmacology and Medical Formulation, Zaporizhzhia State

Medical University, Ukraine.

\section{Відомості про авторів:}

Смойловська Г. П., канА. фарм. наук, доцент каф. фармакогнозії, фармацевтичної хімії і технології ліків, Запорізький Аержавний медичний університет, Україна.

Мазулін О. В., А-р фарм. наук, професор, зав. каф. фармакогнозії, фармацевтичної хімії і технології ліків, Запорізький Аержавний медичний університет, Україна.

Абрамов А. В., А-р меА. наук, професор каф. патофізіології, Запорізький державний медичний університет, Україна. Бухтіярова Н. В., канА. меА. наук, Аоцент каф. фармакології та медичної рецептури, Запорізький Аержавний меАичний університет, Україна.

\section{Сведения об авторах:}

Смойловская Г. П., канА. фарм. наук, Аоцент каф. фармакогнозии, фармацевтической химии и технологии лекарств, Запорожский государственный меАицинский университет, Украина.

Мазулин А. В., А-р фарм. наук, профессор,

зав. каф. фармакогнозии, фармацевтической химии и технологии лекарств, Запорожский государственный медицинский университет, Украина.
Абрамов А. В., А-р меА. наук, профессор каф. патфизиологии, Запорожский государственный меАицинский университет, Украина.

Бухтиярова Н. В., канА. меА. наук, Аоцент каф. фармакологии и медицинской рецептуры, Запорожский государственный медицинский университет, Украина.

Конфлікт інтересів: відсутній.

Conflicts of Interest: authors have no conflict of interest to declare.

НаАійшло Ао реАакції / Received: 18.05.2017

Після Аоопрацювання / Revised: 23.05.2017

Прийнято АО Аруку / Accepted: 04.09.2017 